\title{
RESEARCH IN BRITISH COLONIAL TERRITORIES
}

\begin{abstract}
"COLONIAL RESEARCH 1951-1952"* follows 1 the form of last year's report. Besides the brief report of the Colonial Research Council, to which are appended a list of schemes approved for research grants, April 1, 1951-March 31, 1952, and the report of the Director of the Colonial Products Advisory Bureau for 1951-52, it comprises the ninth annual report of the Colonial Products Research Council, the eighth annual report of the Colonial Social Science Research Council, the seventh annual reports of the Colonial Medical Research Committee and the Committee for Colonial Agricultural, Animal Health and Forestry Research, the fifth annual reports of the Colonial Insecticides and the Colonial Economic Research Committee and annual reports of the Colonial Fisheries Advisory Committee on Fisheries Research, of the Director of the Anti-Locust Research Centre on Locust Research and Control, and of the Tsetse Fly and Trypanosomiasis Committee : lists of publications are appended to the several reports. The Colonial Research Council's report is, as usual, confined to matters not covered by the specialist committees, and its most important feature is the warning it sounds as to the effects of the uncertainty regarding the provision of Colonial Development and Welfare funds after the present Acts expire in March 1956. As the Council here points out, such uncertainty both makes the planning of longterm research impossible and is also hindering the recruitment of research workers for the Colonial territories.
\end{abstract}

The Council's reasonable request for an early clarification of the position is one which should receive prompt response from the Government, and should be carefully noted by scientific workers as well as by the Parliamentary and Scientific Committee. Little is said in these reports about other difficulties in recruiting scientific workers; seventeen research appointments were made during the year, and about forty officers in some ninety posts in the Colonial Agricultural, Veterinary and Medical Services have been declared suitable for transfer to the Colonial Research Service. The Council in this report stresses the importance both of direct contact between research organizations and institutions in Great Britain and the Colonial territories, and of visits of members of the various research advisory committees to the territories where the schemes sponsored by the committees operate.

As was forecast in last year's report, there was a substantial reduction in the number and size of research schemes made during the year : some thirtysix new schemes and fifty-three supplementary schemes, involving grants totalling $£ 868,851$, brought the total allotted to Colonial Development and Welfare Schemes to a net expenditure and commitment of $£ 10,140,000$ at March 31, 1952, of which $£ 9.94$ millions is chargeable against funds provided under

* Colonial Office. Colonial Research 1951-1952: Reports of the Colonial Research Council, Colonial products Research Council, Colonial Social Science Research Council, Colonial Medical Research Committee, Committee for Colonial Agricultural, Animal Health and Forestry Research, Colonial Insecticides Committee, Colonial Economic Research Committee, Tsetse Fly and Trypanosomiasis Research Committee, Colonial Fisheries Advisory Committee, Director of Anti-Iocust Research Centre. (Cmd. 8665.)
Statlonery Office, 1952.) 68. $6 d$. net. the 1945 and 1950 Acts. Additional assistance provided by Colonial Governments or industry since 1940 is estimated at about $£ 3$ millions. Of the gross allocation of $£ 11,100,000$, about $32 \cdot 7$ per cent has been for agricultural, animal health and forestry schemes, 13.9 per cent for medical research, 13.8 per cent for fisheries research, 11.7 per cent for tsetse and trypanosomiasis research, $8 \cdot 8$ per cent for social science and economic research, 6.2 per cent for insecticides research, 4.6 per cent for research sponsored by the Colonial Products Research Council and 3.5 per cent for anti-locust research. About 39.0 per cent of the gross allocation has been for schemes to benefit the East African territories, 18.3 per cent for the West African group, $11 \cdot 1$ per cent for the South-East Asian territories and Hong Kong, 8.7 per cent for the West Indian Colonies, British Guiana and British Honduras and $6 \cdot 2$ per cent for the Central African territories (Northern Rhodesia and Nyasaland). Schemes approved during the year besides those recently noted (cf. Nature, 170, 311 ; 1952) include $£ 28,750$ for the Anti-Locust Research Centre and its extra-mural research, $£ 31,500$ for physiological and biochemical research at Makerere College, Uganda, $£ 26 ; 620$ for the East African Agriculture and Forestry Research Organization, £24,403 for the Nutrition Field Station, Fajara, Gambia, and $£ 17,500$ to enable clove research in Zanzibar to be extended until August 31, 1953.

Work under four of the Economic Co-operation Administration projects mentioned in last year's report was started or continued in 1951-52. An American plant-breeder visited Nigeria to investigate the breeding of improved grain sorghums and maize, and an entomologist was secured for research in Northern Rhodesia into the control of ticks affecting livestock. The African Studies Branch of the Colonial Office is undertaking surveys of particular subjects to meet current Colonial Office needs, and a complete survey of the development of local government in the African territories since 1947 began to appear as supplements to the Journal of African Administration in January 1952. Mr. Ian Small, the newly appointed director of the West African Building Research Organization, was proceeding to the Gold Coast in the summer of 1952 , and Mr. G. A. Atkinson, the Colonial building research liaison officer, who has now visited twenty-five Colonial territories, visited Hong Kong and the South-East Asian territories and also Aden and Cyprus during January-May 1952. His report on his visit to the Caribbean area was presented during the year, and a review of aided self-help housing, based on information gained during the tour, was circulated to all Colonial governments. Mr. Atkinson reached the conclusion that little or no organized scientific research into building problems is possible in the area in the immediate future. Much could be done, however, to improve building materials by making technical information more readily available and by providing better facilities for training building technicians and for testing materials.

Publication of Volume 3 of the "Demographic Survey of the British Colonial Empire" is expected early in 1953. Censuses were taken during the year 
in North Borneo and Gambia and, for the nonAfrican population and for Africans in employment, in Northern Rhodesia. The Directorate of Colonial (Geodetic and Topographic) Surveys moved into new headquarters at Tolworth in June 1951; but little progress is reported in recruiting field-survey staff. A chain of triangles has been reconnoitred, beaconed and observed from Eastern Uganda (near Mount Elgon) down the east side of Lake Victoria to Tanganyika. Most of the southern half of Basutoland has been covered with secondary triangulation. An additional twenty geologists were appointed during the year, and the strength of the overseas scientific staff was 180 in 1951 , compared with 58 in 1947, although there is still a shortage of experienced geologists trained in mapping, petrology and mineralogy. The total area geologically mapped during the year increased considerably. Research continues at various institutions in the United Kingdom on the economic production of Columbian minerals, iron ore and apatite from the soils surrounding the Sukulu carbonatite ring-structure in Uganda. Good progress is being made in the examination of coalfields in Tanganyika, and the report welcomes the growing practical interest of the universities in Great Britain in Colonial geology.

Investigations undertaken in Uganda by the British Paper and Board Industry Research Association on the suitability of local fibres for incorporation in a pulp for the manufacture of a kraft-type of paper for: containers have given promising results, and a paper entitled "Some Notes on the Durability of Paint in Tropical Climates" has been prepared, with particular reference to the humid climate of Singapore. Progress continued in the installation of radiosonde/radar wind stations for the study of upperwind conditions, and regular observations to a height of $60,000 \mathrm{ft}$. are now made by stations established at Aden, Gibraltar, Lagos, Malta and Nairobi. In the oceanographic research to which the Colonial Office contributes, some new instruments are being developed, including a simple method of recording the changes in depth of a mid-water trawl, by measuring the changes in pressure in a rubber bag attached to the trawl, and connected to the ship by a reinforced hose-pipe. Discovery by the R.R.S. William Scoresby of the breeding ground of the pilchard (Sardinops sagax) enabled detailed information to be supplied to Colonial fishery officers in West Africa. The work of the Colonial Liaison Officer at the Road Research Laboratory in Britain is attracting increasing attention from Colonial engineers, and a report is being prepared on his visit in October and November 1951 to Northern Rhodesia and Nyasaland, where the same road problems, broadly speaking, were met as in East and West Africa, though the soils appear to present less difficulty than in East Africa. It is proposed to place the work of the Colonial Products Advisory Bureau, which covers much the same field as that of the Colonial Products Research Council, under a common directorship with the latter body early in 1953. During 1951-52 the Bureau has carried out work on the chromatographic separation of the active principles of pyrethrum, on distilled lime oil from Zanzibar, gum arabic from Tanganyika and the Somaliland Protectorate, cattle hides from East and West Africa, the drying of goat skins, the utilization of Brachystegia wood from Tanganyika for paper-making, and the tanning properties of the barks of Eucalyptus robusta and $E$. saligna from Uganda.
The ninth annual report of the Colonial Products Research Council stresses the value of the work of the Colonial Microbiological Research Institute and of the work carried out there on the fermentation of the cocoa bean. The results already obtained are likely to prove of immediate value to plant-breeders, as they enable commercial evaluation to be made of small samples of beans. A provisional patent has been taken out to cover the preparation of the antibiotic comirin. Although much work is required to determine the most efficient method of preparation and little is yet known of its chemical structure, clinical trials both in Trinidad and in Jamaica have indicated that the fungus skin infections Tinea corporis, $T$. cruris and $T$. interdigitale respond to topical applications of comirin, and that it is also effective in cases of 'tropical ear' infection due to Aspergillus flavus or Candida parapsilosis, but not when the infection was caused by a Gram-negative, motile or non-motile short rod. An investigation is being undertaken on the possibility of growing in the tropics a yeast with a high ergosterol content.

The Hankey Culture Collection now contains more than 500 specimens, of which 84 were isolated from Trinidad sources during the year; 60 cultures were supplied to scientific institutions and commercial firms. With the completion of the Sugar Technological Laboratory in Trinidad, Prof. L. F. Wiggins has been able to examine the possible economic uses of some of the products derived from sugar. Two hydrocarbon solvents available locally proved satisfactory substitutes for benzene in extracting the wax from the filter mud, and by treating the crude wax with fusel oil, a light yellow or grey wax, melting point $78^{\circ}-80^{\circ}$, which appears to be suitable for various industrial purposes, can be readily obtained. The possibility of utilizing, on a manufacturing scale, the improved processes for the preparation of lævulinic and lactic acids from sucrose worked out in the University of Birmingham is now being studied in Trinidad, and a successful process, using an alkaline solution, has been discovered for isolating the cellulose from bagasse in a form suitable for the manufacture of paper.

Equipment has at last been supplied for the special laboratory at the Forest Products Research Laboratory, Princes Risborough, and a series of hardboards with good properties has been obtained from Wallaba wood. Work on the constituents of Colonial hardwoods being carried out in the University of Nottingham in collaboration with the Princes Risborough Laboratory is expected to throw light on the problem of the resistance of timbers to insect and fungal attack. Further carbohydrate investigations carried out in the University of Birmingham have succeeded in preparing tripotassium $\alpha$-D-glucuronate-1-phosphate, which is already proving of value in the enzymic syntheses of polyglucuronides. In further work on polysaccharides, evidence has been obtained that dextran is a mixture of materials with a wide range of molecular weights, and that while the dextran from Betacoccus arabinosaceus has "an average chain-length of six to seven glucose units, the cross-linking is not of the $1: 4$ type. Investigations on the production of bacterial cellulose from sugar have reached the stage when pilot plant trials are desirable.

Improved methods have been developed for the isolation and purification of starch-metabolizing enzymes, and a clearer definition of their functions is now possible. The $R$-enzyme possesses only the 
function of irreversible hydrolytic scission of the branch links in amylopectin. The $Z$-enzyme is a $\beta$-glucosidase, and with its aid it has been found that amylase contains branch linkages. The $Q$-enzyme has been recognized as a transglucosidase. An excellent oil has been extracted from the eighteen tons of heatdried oil-seeds of Tetracarpidium conophorum received from Nigeria and is now being distributed in the paint industry for technical evaluation. Progress is reported in the study of the germination factor of Striga, and highly satisfactory results were obtained in Nigeria with a new machine for harvesting $\mathrm{Hibiscus}$ cannabinus, and accordingly further trials are being made with jute in British Guiana.

The eighth annual report of the Colonial Social Science Research Council refers to the great restraint which the Council has had to exercise in making new grants. Since October 1, 1951, the Council has had to operate within a limit of $£ 325,000$ until March 31 , 1956 , and on March 31,1952 , only some $£ 200,000$ was uncommitted. Accordingly, it was necessary to refuse applications for new grants which were not already receiving considerable financial support from other sources. Although the recruitment position for experienced research staff improved, difficulty is still being encountered in recruiting senior staff capable of organizing research, and in such special categories as demography and law. Much of the present report is occupied by a retrospect of the work of the Council since 1945, and there are appended to it annual reports for 1951-52 from the East African Institute of Social Research, Makerere College, the West African Institute of Social and Economic Research, Ibadan, the Rhodes-Livingstone Institute, and the Institute of Social and Economic Research, University College of the West Indies, as well as a list of publications by research workers assisted by the Council.

Commenting on the progress of Colonial studies in British universities, the Council refers to the work of the Department of Anthropology in the University of Manchester, which is closely associated with the work of the Rhodes-Livingstone Institute on Central African Studies, the work on race relations carried out under the auspices of the Department of Anthropology in the University of Edinburgh, and to the analysis of the social organization and types of society in the highlands of New Guinea and the studies of the appearance of cargo cults in the Pacific Islands and of the Pacific islander in commerce and industry being carried out by the Department of Anthropology of the Australian National University. The Survey of African Marriage and Family Life has been completed and is now in the press. Other reports in the press are Mr. J. N. D. Anderson's synoptic survey of the present position of Islamic law in the British African territories and Aden, Prof. C. M. Dohe's study of the Bantu languages of Southern Africa and the West Indian volume of the late Dr. Kuczynski's "Demographic Survey of the British Colonial Empire", while numerous other investigations are being prepared for publication. The East African Institute of Social Research has completed a survey of the European, Indian and African inhabitants of Jinja township and continued village surveys of immigrant labour in Buganda. A study of the present method of selection and training of African leaders in East Africa is proposed, as well as a survey of the Indian community in and around Kampala. At the West African Institute of Social and Economic Research, the inquiry into the Nigerian monetary and banking system is being completed and also that into Yoruba social and economic organizations. Definite proposals have been made regarding the functions of the Institute in relation to the Nigeria produce-marketing boards. The major event at the Rhodes-Livingstone Institute was the appearance of its first major publication, "Seven Tribes of British Central Africa". The Institute of Social and Economic Research, Jamaica, reports progress in the projects for the preparation of national income estimates, the determination of the trend in consumption patterns in Barbados and on experiences of management in the adaptation and training of Jamaican industrial workers.

(To be continued)

\section{INDUSTRIAL RADIOLOGY GROUP OF THE INSTITUTE OF PHYSICS}

\section{MEETING IN SHEFFIELD}

$T$ HE summer meeting of the Industrial Radiology Group of the Institute of Physics was held at Crewe Hall, Sheffield, during July 3-5. The success of the meeting was in no small way due to J. F. Hinsley and H. S. Peiser, who were responsible for the local arrangements, and to the staffs at Crewe Hall and at the various companies and institutions visited.

A day and a half were devoted to lectures, the opening session on "Training in Industrial Radiology" being given in two parts, the first by Mr. J. C. Rockley, of the Aeronautical Inspection Directorate, Harefield, and the second by Mr. J. D. Hislop, of Solus-Schall, Ltd. Mr. Rockley pleaded for a longer training course than is at present available for industry, with a recognized award, and spoke of what is being done by the exploratory committee of the City and Guilds of London Institute, to which the Institute of Physics has made recommendations.

Mr. Hislop thought that the maximum tuition in the time available in a part-time course can only be given if a good deal of this is devoted to theoretical work. In dealing with the special problems of weld examination, he put forward a plea for standards of interpretation which could be incorporated in any final training scheme and stressed the importance of correct identification and of orderly reporting. He thcught that the training of a radiographer is essentially a long-term one, and suggested that managerial staff should become more familiar with the limitations of the method.

The first paper during the afternoon was given by Dr. R. Jackson, of the British Coal Utilization Research Association, on "The Presentation of Results in Radiography with Special Reference to the Terminology of Casting Defects". Dr. Jackson stressed the need for as good a radiograph as could be obtained, followed by careful interpretation, with as full information about the casting as possible in advance. $\mathrm{He}$ concluded with a description of the many difficulties which had been met in drawing up the proposed British Standards Institution terminology.

The second afternoon paper had the title "Economic Aspects and Administration of an Industrial Radiology Department" and was a joint paper by E. W. Colbeck, F. Cousans, H. S. Peiser and J. R. Rait (all of Hadfields, Ltd.). Mr. Peiser, who delivered the lecture, 